\title{
Analisis Viskositas Slurry Propelan Untuk Akurasi Karakterisasi Rheologi Berbasis Perekat Hidroxy Terminated Polybutadiene Dengan Plasticizer Dioctyl Adipate
}

\author{
Retno Ardianingsih ${ }^{1 *}$, Andri Cahyo Kumoro ${ }^{2)}$ \\ 1) Pusat Teknologi Roket, Lembaga Penerbangan dan Antariksa Nasional \\ Jl. Raya Lapan No. 2 Mekarsari, Rumpin, Bogor, Indonesia 16350 \\ ${ }^{2)}$ Departemen Teknik Kimia, Universitas Diponegoro \\ Jl. Prof. Soedarto, SH, Kampus UNDIP Tembalang, Semarang, Indonesia 50275
}

\begin{abstract}
Abstrak
Analisis rheologi perlu dilakukan terhadap slurry propelan untuk mengetahui viskositas dan castability-nya. Hal ini berpengaruh pada tingkat homogenitas dan nilai Isp sebagai karakteristik utama propelan padat komposit. Penelitian ini bertujuan untuk mengetahui karakteristik rheologi slurry propelan berbasis HTPB dan DOA menggunakan analisis viskositas. Metode pengukuran viskositas dilakukan dengan parameter suhu, waktu curing dan shear rate. Hasil pengukuran menunjukkan bahwa viskositas menurun dengan kenaikan suhu dan juga sebaliknya, viskositas meningkat dengan bertambahnya waktu curing. Melalui persamaan Power Law, diperoleh Koefisien konsistensi (K) antara 2,1148-2,2877 yang nilainya meningkat seiring dengan turunnya temperatur. Bertambahnya nilai $K$ mengartikan energi yang dibutuhkan oleh unit operasi untuk mencetak propelan ke dalam tabung cetakan juga semakin meningkat. Sedangkan nilai indeks sifat alir (n) antara 0,1535 - 0,5128 menunjukkan bahwa slurry propelan merupakan fluida Non-Newtonian dengan perilaku shearthinning (pseudoplastik) karena $n<1$.
\end{abstract}

Kata kunci: laju geser; rheologi; slurry propelan; viskositas; waktu curing

\begin{abstract}
[Title: Viscosity Analysis of Propellant Slurry for Accuracy of Rheological Characterization Based on Hydroxy Terminated Polybutadiene Adhesives With Dioctyl Adipate Plasticizer] Rheological analysis needs to be done on propellant slurry to determine its viscosity and castability. These affects on homogeneity level and Isp value as the main characteristics of composite solid propellant. This study aims to determine the rheological characteristics of propellant slurry based on HTPB and DOA using viscosity analysis. The method of measuring viscosity was carried out with parameters such as temperature, curing time and shear rate. The measurement results showed that viscosity decreases with increasing temperature and vice versa, viscosity increases with increasing curing time. Through the Power Law equation, a consistency coefficient $(K)$ is obtained between 2.1148-2.2877 whose the value increases with decreasing temperature. Increasing the $K$ value means the energy needed by the operating unit to cast propellant into the mold tube is also increasing. While the flow index value ( $n$ ) between 0.1535 - 0.5128 showed that propellant slurry is a Non-Newtonian fluid with shear-thinning (pseudoplastic) behavior because $n<1$.
\end{abstract}

Keywords: shear rate; rheology; propellant slurry; viscosity; curing time

\section{Pendahuluan}

Bahan bakar yang digunakan untuk menggerakkan roket disebut propelan. Propelan berdasarkan wujud (fase) fisiknya diklasifikasikan

\footnotetext{
${ }^{*}$ Penulis Korespondensi.

E-mail: re_ardian@yahoo.com
}

menjadi dua, yaitu propelan padat dan propelan cair (Kit \& Evered, 1960). Propelan cair atau propelan fluida adalah propelan yang berwujud cair. Di dalam sistem propelan cair, antara bahan bakar dan oksidator keduanya merupakan zat cair. Umumnya, sistem propelan cair memberikan nilai Isp (impuls spesifik) yang lebih tinggi dibandingkan propelan padat. Isp merupakan merupakan ukuran kualitas propelan yang penting (Abdillah dan Ardianingsih, 2014). Namun 


\section{TEKNIK, 40 (3), 2019, 155}

propelan cair membutuhkan tingkat kesiapan peralatan teknologi yang lebih tinggi pula, yang terdiri dari sejumlah valve dan regulator yang harus sangat akurat untuk mencapai pengukuran yang tepat dari kedua cairan (Sutton \& Biblarz, 2001). Jenis propelan padat merupakan energi utama untuk motor roket dan misil pertahanan karena memberikan jaminan yang dapat diandalkan untuk kestabilan terbang dan kendali presisi (Ke $d k k$. 2014). Misil atau yang dikenal dengan rudal (peluru kendali) adalah wahana militer yang memiliki sistem kendali untuk mencari target atau menyesuaikan arah, sedangkan roket digunakan untuk wahana tanpa sistem kendali. Propelan terdiri dari oksidator berbentuk partikel dan bahan bakar berbentuk larutan polimer yang sangat kental, yang apabila kedua bahan tersebut dicampurkan akan mengeras dan membentuk padatan lentur akibat polimerisasi selama proses yang disebut curing.

Pada dasarnya, sebagian besar propelan padat komposit disusun oleh bahan oksidator yang menyumbang persentase hingga $80 \%$. Sisanya terdiri dari bahan bakar, perekat, curing agent dan bahan aditif lainnya (Hagen, 2014). Sejauh ini penelitian formulasi yang dilakukan di LAPAN hanya melibatkan komponen utama seperti amonium perklorat (AP) sebagai oksidator, aluminium serbuk sebagai bahan bakar, hydroxy terminated polybutadiene (HTPB) sebagai perekat dan toluene diisocyanate (TDI) yang berfungsi sebagai curing agent. Penggunaan bahan-bahan aditif yang lain sebenarnya bisa berfungsi sebagai plasticizer, curing catalyst, combustion stabilizer, bonding agent dan lainnya (Setyaningsih, 2010). Dari berbagai bahan aditif yang berfungsi sebagai plasticizer, LAPAN menggunakan plasticizer dioctyl adipate (DOA).

Kinerja roket yang baik ditunjukkan dengan produksi energi yang optimal. Formulasi dan komposisi yang tepat dari bahan - bahan penyusun propelan padat komposit sangatlah diperlukan untuk memperoleh propelan dengan karakteristik yang diinginkan. Dalam pembuatan propelan padat komposit, salah satu karakteristik yang menjadi target utama adalah impuls spesifik (Isp). Propelan dengan kinerja baik adalah propelan yang memiliki nilai Isp yang tinggi dengan kisaran 240 - 260 detik (Kit, 1960). Sebagai contoh formulasi propelan hasil kerjasama antara LAPAN-Hanwha Korea yang memiliki Isp tinggi sebesar 248,6 detik (Hartaya, Abdillah \& Ardianingsih, 2014).

Langkah untuk menaikkan Isp adalah dengan memperbesar prosentase kandungan padatan (Al serbuk dan AP) untuk meningkatkan energi yang dibebaskan pada pembakaran propelan (Marothiya $d k k ., 2017)$. Namun, kemudian timbul masalah karena penambahan bahan-bahan tersebut dapat meningkatkan viskositas dan menurunkan prosentase elongasi propelan. Faktor utama yang mempengaruhi viskositas slurry propelan telah disebutkan oleh (Muthiah, Khrisnamurthy \& Gupta, 1991) yaitu kandungan padatan, ukuran partikel, bentuk partikel padatan dan distribusi oksidator terhadap perbedaan temperatur. Kenaikan viskositas sangat tidak diharapkan karena akan menyulitkan proses casting propelan.

Di seluruh dunia ada beberapa teknik yang diadopsi untuk mencetak propelan yaitu vacuum casting, pressure casting, bayonet casting dan lainnya. Pemilihan metode casting yang sesuai didasarkan pada parameternya yaitu tipe propelan, karakteristik rheologi dari slurry propelan, ukuran jaring dan bentuk grain dari motor roket (Thiyyarkandy $d k k$., 2012). Viskositas ideal untuk pressure casting ialah 14.000 - 18.000 poise (Jawalkar dkk., 2007). Sedangkan, untuk vacuum casting dibutuhkan viskositas dibawah 16.000 poise. Proses casting propelan yang tidak sempurna akan mengakibatkan kerapuhan karena propelan yang tidak homogen. Sedangkan penurunan prosentase elongasi dapat menyebabkan kegagalan dalam menyerap tekanan yang terjadi pada motor roket (Dombe $d k k ., 2008$ ).

Dalam penelitian ini, dilakukan pengukuran viskositas slurry propelan menggunakan HTPB dan DOA. HTPB digunakan sebagai perekat dan memiliki fungsi untuk mengikat oksidator dan bahan bakar. Sedangkan DOA sebagai plasticizer memiliki fungsi untuk menurunkan viskositas karena dapat membuat slurry menjadi lebih encer. Secara spesifik, dipelajari tentang sifat rheologi pada proses pembuatan propelan padat komposit. Parameter untuk pengukuran viskositas adalah perbedaan shear rate, perbedaan temperatur dan waktu curing. Berdasarkan data karakteristik rheologi, dapat dilakukan suatu pemodelan sebagai acuan untuk memprediksi viskositas slurry propelan pada formulasi propelan. Selain itu, data viskositas dapat juga digunakan untuk menghitung laju aliran, perpindahan panas dan perpindahan massa pada berbagai bagian peralatan industri pembuatan propelan (Abdulagatov \& Azizova, 2019).

\section{Bahan dan Metode}

\subsection{Material}

Formulasi propelan padat komposit dibagi menjadi dua bagian yaitu kandungan padatan dan kandungan cairan. Kandungan padatan terdiri dari AP bimodal dan Al serbuk, kandungannya bisa mencapai 80-85 \% dari total berat propelan. Kandungan cairan terdiri dari HTPB, TDI dan DOA, dengan kandungan mencapai maksimal $20 \%$ dari berat propelan. Kelima bahan penyusun propelan tersebut diperoleh dari Dalian Chlorate Co.Ltd, China. Rasio oksidator AP kasar $200 \mu \mathrm{m}$ dan AP halus $50 \mu \mathrm{m}$ sebesar 1:1. Aluminium serbuk $\pm 30 \mu \mathrm{m}$ sebagai bahan bakar logam akan menggunakan partikel bentuk bola, digunakan sebanyak $8 \%$. Perekat HTPB dan curing agent TDI akan digunakan pada rasio HTPB:TDI $=15: 1$. Plasticizer DOA akan digunakan pada tahap pre-mixing dengan prosentase kandungan DOA sebesar $3 \%$ terhadap berat total slurry propelan. 


\section{TEKNIK, 40 (3), 2019, 156}

\subsection{Peralatan}

Peralatan utama yang digunakan antara lain mixer horizontal tipe $\mathrm{Z}$ blade berkapasitas 5 liter dengan sistem batch, viskometer Brookfield dengan tipe DV3T extra HA model DX3THAKBO dan spindle nomor 7 , handmade slab berukuran $5 \mathrm{~cm} \times$ $5 \mathrm{~cm} \times 10 \mathrm{~cm}$. Rangkaian unit mixer horizontal tipe $\mathrm{Z}$ blade dapat dilihat pada Gambar 1, yang merupakan peralatan untuk mencampur dan mengaduk bahanbahan penyusun propelan. Unit ini terdiri dari tangki mixer (1), yang dilengkapi dengan tutup / mixer lid (2) dan pengukur tekanan (11), di dalam tangki terdapat Z blade mixer (4) yang digerakkan oleh motor blade (10). Roda penggerak mixer terdapat di rumah seal (3). Tangki waterbath (5) digunakan untuk menampung air yang telah dipanaskan oleh pemanas air (6). Oleh pompa air (9), air panas tersebut dialirkan ke dalam jaket tangki melalui pipa inlet (7) dan dikembalikan ke tangki waterbath melalui pipa outlet (8) untuk dipanaskan kembali.

(a)

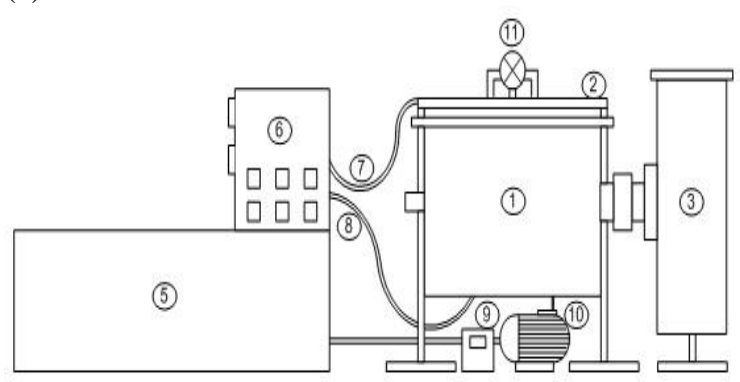

(b)

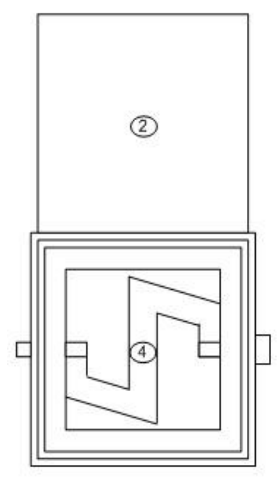

Gambar 1. Rangkaian unit mixer horizontal tipe Z blade dilengkapi waterbath dengan kondisi: (a) close lid tampak depan; (b) open lid tampak atas

\subsection{Pelaksanaan Penelitian}

Penelitian dilakukan di laboratorium Komposisi Dasar, Pusat Teknologi Roket, LAPAN Bogor. Tahapan proses yang dilakukan terdiri dari proses pre-mixing, mixing, dan pengukuran viskositas. Variabel berubah yang digunakan pada saat pengukuran viskositas antara lain perbedaan temperatur, perbedaan shear rate dan waktu curing. Nilai temperatur saat pengukuran viskositas, divariasi pada suhu $40,45,50,55$ dan $60{ }^{\circ} \mathrm{C}$. Suhu ini

digunakan karena menyesuaikan dengan suhu saat proses curing propelan yang mencapai $60{ }^{\circ} \mathrm{C}$ dalam oven. Slurry hasil end mixing yang akan diukur viskositasnya ditempatkan dalam wadah handmade slab yang terbuat dari plat aluminium berukuran $5 \times 5 \times 10 \mathrm{~cm}$, kemudian diisi dengan slurry propelan sebanyak kurang lebih $450 \mathrm{~mL}$ dengan tujuan supaya spindle dapat tercelup sekitar $7 \mathrm{~mm}$ ke dalam slurry. Viskositas slurry kemudian diukur pada menit ke-0 setelah mixing (end of mixing) dilanjutkan hingga 4 jam berikutnya, dengan jeda 60 menit di setiap pengukurannya. Selama pengukuran dalam rentang waktu 60 menit tersebut (pada 60 menit pertama, 60 menit kedua dst) dilakukan variasi shear rate sekaligus sebanyak delapan variasi yaitu 2,$5 ; 3 ; 5 ; 8$; 10; 15; 20 dan $30 \mathrm{rpm}$.

Perilaku aliran slurry dikarakterisasi melalui pengukuran viskositas pada laju geser yang rendah. Pemilihan ini didasarkan pada syarat penggunaan prosentase torsi yang sebanding dengan tegangan geser yang diterapkan, yang mana prosentase torsi $>10 \%$ adalah rentang terukur yang dianggap akurat untuk kombinasi spindle dan kecepatan viskometer Brookfield (Abhay $d k k ., 2010$ ). Untuk mendapatkan pembacaan nilai torsi antara 10 hingga $100 \%$, dilakukan pemilihan spindle dan kecepatan putar secara trial and error. Jika torsi terbaca lebih dari 100 , pilih kecepatan yang lebih rendah dan/atau spindle yang lebih kecil. Begitu juga sebaliknya jika pembacaan torsi kurang dari 10 (Brookfield, 2014). Gambar 2 menunjukkan pengukuran viskositas slurry propelan menggunakan viskometer Brookfield.
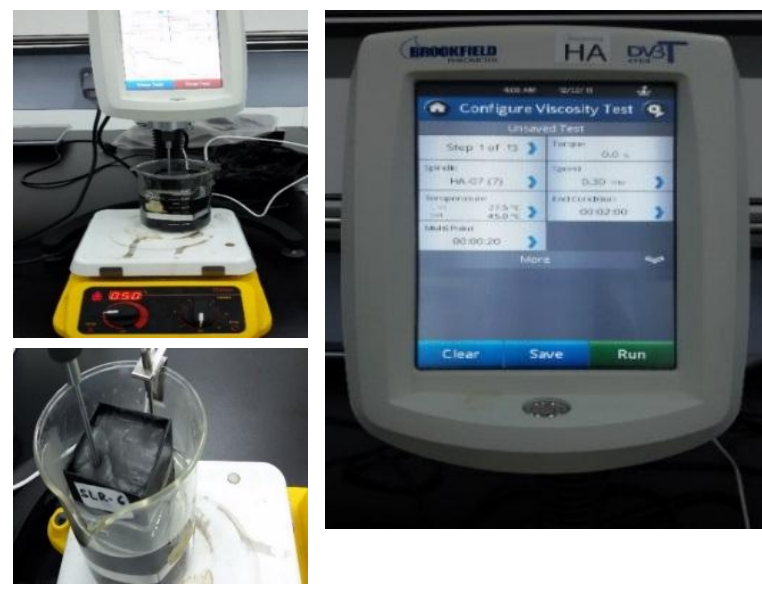

Gambar 2. Tampak depan dan tampak atas pengukuran viskositas slurry propelan dengan penggunaan hotplate dan viskometer brookfield

2.4. Prosedur Pengolahan Data Viskositas

2.4.1. Pemodelan Viskositas Slurry Propelan Menurut Waktu Curing

1. Menentukan Persamaan 1 ke dalam bentuk logaritma.

$$
\eta(t)=\eta_{0} \cdot e^{k \eta t}
$$

2. Menjadi Persamaan 2. 


$$
\ln \eta(t)=\ln \eta_{0}+k_{\eta} t
$$

3. Membuat grafik dengan menerapkan $\ln \eta$ terhadap waktu (t) yang slope-nya merupakan laju konstan kenaikan viskositas.

4. Memasukkan data nilai $\ln \eta$ (poise) diplot terhadap waktu curing $(\mathrm{t})$ pada berbagai suhu

5. Membuat trendline model linier dari grafik yang terbentuk.

6. Dari garis regresi linier pada grafik, nilai slope menunjukkan laju tetap $\left(\mathrm{k}_{\eta}\right)$ dan nilai intercept menunjukkan nilai viskositas pada saat $\mathrm{t}=0$ $\left(\eta_{0}\right)$.

2.4.2. Pemodelan Viskositas Slurry Propelan Menurut Laju Geser

1. Memasukkan data nilai ln (poise) versus laju geser (rpm) ke dalam grafik sesuai Persamaan 3.

$$
\tau=K \cdot \gamma^{n}
$$

2. Menghasilkan garis lurus antara viskositas nyata $(\eta)$ versus laju geser (rpm) menjadi Persamaan 4.

$$
\eta=K \cdot \gamma^{n-1}
$$

3. Menghasilkan grafik logaritmik hubungan antara $\ln \gamma$ (rpm) vs $\ln \eta$ (poise) dengan persamaan logaritma 5 hingga 7.

$$
\begin{aligned}
& \ln \eta=\ln \left(K \gamma^{n-1}\right) \\
& \ln \eta=\ln K+\ln \gamma^{n-1} \\
& \ln \eta=\ln K+(n-1) \cdot \ln \gamma
\end{aligned}
$$

4. Menghasilkan slope dan intercept yang masing-masing merupakan nilai dari indeks laju alir (n) dan koefisien konsistensi (K), pada semua variasi suhu dan waktu curing.

\section{Hasil dan Pembahasan}

\subsection{Pemodelan Viskositas Slurry Propelan Menurut Waktu Curing}

Pemodelan semi empiris dapat digunakan untuk memprediksi variasi kenaikan viskositas selama proses curing dengan persamaan (1) yang memberikan hubungan antara perubahan viskositas ( $\eta$ ) dengan kenaikan waktu curing (t). Dalam hal ini, $\eta_{0}$ merupakan viskositas (poise) pada saat $\mathrm{t}=0$ menit dan notasi $\mathrm{k}_{\eta}$ merupakan laju konstan kenaikan viskositas $\left(\mathrm{min}^{-1}\right)$.

Oleh karena itu, membuat grafik dengan menerapkan $\ln \eta$ terhadap waktu (t) seharusnya menghasilkan garis yang linier di mana slope-nya merupakan laju konstan kenaikan viskositas. Nilai ln $\eta$ (poise) yang merupakan data hasil eksperimen, kemudian diplot terhadap waktu curing (t), pada suhu $40^{\circ} \mathrm{C}, \quad 45^{\circ} \mathrm{C}, \quad 50^{\circ} \mathrm{C}, \quad 55^{\circ} \mathrm{C}$ dan $60^{\circ} \mathrm{C}$ sehingga menghasilkan grafik seperti pada Gambar 3 .

Shear rate yang digunakan dalam grafik saat pengukuran adalah 2,5 rpm. Dari grafik yang terbentuk kemudian dibuat trendline-nya dengan model linier. Hasil regresi linier menunjukkan bahwa laju kenaikan viskositas slurry propelan saat

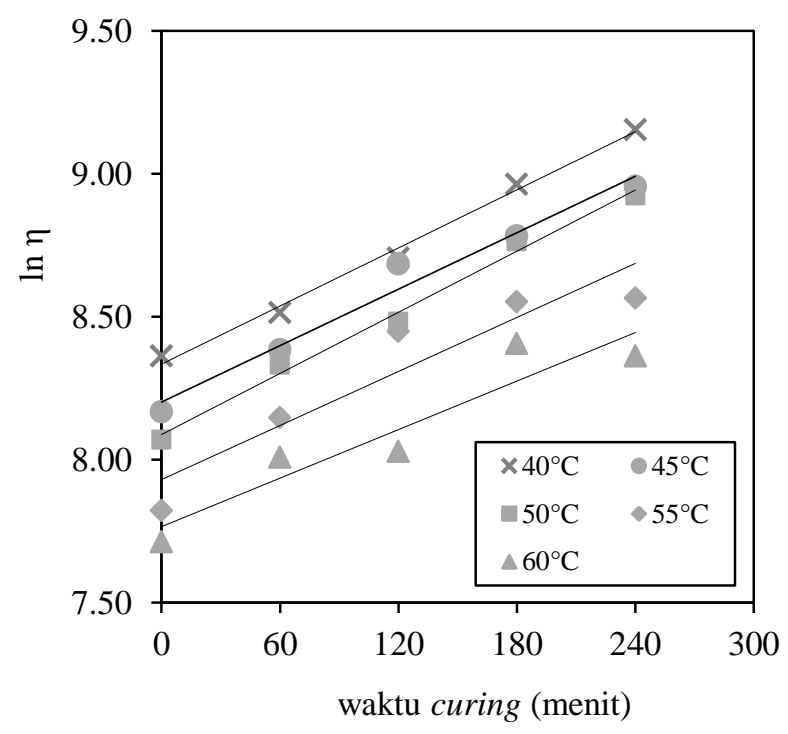

penambahan waktu curing merupakan proses orde 1 .

Gambar 3. Hubungan antara $\ln \eta$ vs waktu curing untuk slurry propelan pada lima variasi suhu

Berdasarkan garis regresi linier pada grafik $\ln \eta$ vs waktu curing, nilai slope menunjukkan tetapan laju reaksi $\left(k_{\eta}\right)$ dan nilai intercept menunjukkan nilai viskositas pada saat $t=0\left(\eta_{0}\right)$. Sedangkan nilai $\eta_{0}$ dan $\mathrm{k}_{\eta}$ yang diperoleh dari persamaan (2) pada Gambar 3 ditunjukkan dalam Tabel 1.

Tabel 1. Nilai dari viskositas saat $\mathrm{t}=0\left(\eta_{0}\right)$ dan laju tetap $\left(\mathrm{k}_{\eta}\right)$ propelan slurry pada lima variasi suhu yang berbeda

\begin{tabular}{cccc}
\hline $\begin{array}{c}\text { Suhu } \\
\left({ }^{\circ} \mathrm{C}\right)\end{array}$ & $\begin{array}{c}\text { Koefisien } \\
\text { Determinasi }\left(\mathrm{R}^{2}\right)\end{array}$ & $\begin{array}{c}\mathrm{k}_{\eta} \times 10^{3} \\
\left(\text { menit }^{-1}\right)\end{array}$ & $\begin{array}{c}\eta_{0} \\
(\text { poise })\end{array}$ \\
\hline 40 & 0,9532 & 3,6 & 4164,29 \\
45 & 0,9007 & 3,4 & 3645,32 \\
50 & 0,9916 & 3,3 & 3253,22 \\
55 & 0,8660 & 3,1 & 2784,43 \\
60 & 0,8839 & 2,8 & 2357,84 \\
\hline
\end{tabular}

Nilai $\eta_{0}$ dan $k_{\eta}$ pada Tabel 1 menunjukkan bahwa bertambahnya suhu mengakibatkan viskositas nyata slurry (apparent viscosity) pada saat $\mathrm{t}=0$ mengalami penurunan, yang mengindikasikan karakteristik slurry propelan menjadi lebih encer. Viskositas fluida akan turun dengan naiknya suhu, berkebalikan dengan viskositas gas yang justru akan naik dengan meningkatnya suhu. Pemanasan zat cair menyebabkan molekul-molekulnya memperoleh energi. Molekul - molekul cairan tersebut akan bergerak sehingga gaya interaksi antar molekul melemah. Dengan demikian viskositas cairan akan turun dengan kenaikan temperatur.

Pada slurry propelan, setelah proses mixing dan seiring berjalannya waktu curing, maka viskositas akan meningkat disebabkan terjadinya proses polimerisasi antara gugus hidroksil dari HTPB dengan 


\section{TEKNIK, 40 (3), 2019, 158}

gugus isosianat dari TDI. Hal ini mengakibatkan terbentuknya suatu zat pengikat bagi kandungan padatan sehingga meningkatkan viskositas slurry propelan (Restasari, Budi \& Hartaya, 2018).

Nilai $\quad 0,8000$ sampai dengan 1,000 menginterpretasikan bahwa tingkat hubungan antar dua variabel sangat kuat. Koefisien determinasi pada regresi linear sering diartikan sebagai seberapa besar kemampuan semua variabel bebas dalam menjelaskan varian dari variabel terikatnya. Sebagai contoh jika $\mathrm{R}^{2}=0,9532$ maka pengaruh variabel curing time terhadap nilai viskositas adalah sebesar $95,32 \%$; sedang sisanya $4,68 \%$ dipengaruhi oleh faktor lain.

\subsection{Pemodelan Viskositas Slurry Propelan Berdasarkan Laju Geser}

Viskositas dari beberapa fluida Non-Newtonian dapat berubah dengan variasi laju geser sehingga harus dikarakterisasi oleh lebih dari satu parameter. Viskositas dari beberapa fluida Non-Newtonian tidak akan berubah dengan durasi waktu laju geser (disebut fluida time dependent Non-Newtonian). Hal tersebut dinyatakan dengan model power law dalam hal kecepatan putar spindle (Dak dkk., 2008).

Persamaan Ostwald, yang juga dikenal sebagai persamaan Power Law, diaplikasikan untuk fluida shear-thinning yang tidak menunjukkan nilai yield stress (Björn dkk., 2012). Pada karakterisasi rheologi suatu slurry propelan, persamaan power law sering digunakan secara luas dalam analisis teori dan perhitungan praktis. Persamaan power law tersebut secara matematis dituliskan dalam persamaan (3).

Dalam, hal ini, persamaan (3) tersebut menunjukkan bahwa $\tau$ adalah tegangan geser $\left(\right.$ dynes $\left./ \mathrm{cm}^{2}\right), \quad \mathrm{K}$ adalah koefisien konsistensi (dynes $\left./ \mathrm{cm}^{2} \cdot \operatorname{det}^{\mathrm{n}}\right), \gamma$ adalah shear rate $(\mathrm{rpm})$ dan $\mathrm{n}$ adalah indeks sifat alir. Dari persamaan power law tersebut, viskositas dapat dinyatakan dengan persamaan (4). Laju geser kurang lebih mendekati fungsi linier dari kecepatan putar (rpm) viskometer Brookfield, sehingga perputaran rotasi spindle saat pengukuran viskositas dianggap sebagai shear rate/laju geser pada analisis rheologi.

Gambar 4 menunjukkan grafik logaritmik dari viskositas slurry propelan pada variasi suhu $55^{\circ} \mathrm{C}$ dengan berbagai waktu curing. Plot serupa juga diperoleh untuk sampel slurry propelan pada suhu lainnya.

Berdasarkan Gambar 4 diperoleh slope dan intercept yang masing-masing merupakan ukuran nilai dari indeks laju alir (n) dan koefisien konsistensi (K). Data viskositas hasil eksperimen dipasang pada fungsi eksponensial dan viskositas slurry propelan pada waktu curing tertentu kemudian dihitung dan selanjutnya diplotkan terhadap shear rate (rpm). Dengan demikian koefisien determinasi persamaan linier $\left(\mathrm{R}^{2}\right)$, nilai $\mathrm{n}$ serta nilai $\mathrm{K}$ yang dihasilkan dari setiap grafik logaritmik viskositas slurry propelan dari 5 (lima) variasi suhu yang berbeda dapat dirangkum ke dalam Tabel 2.

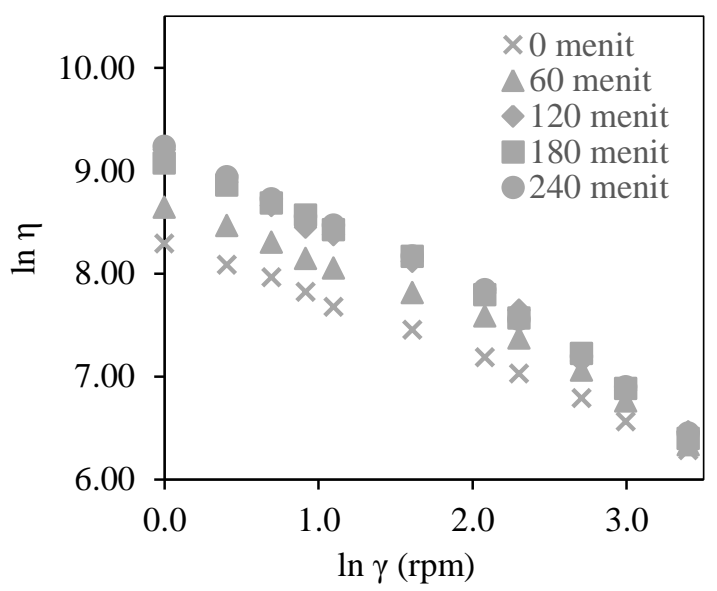

Gambar 4. Grafik hubungan antara $\ln \gamma(\mathrm{rpm})$ vs $\ln \eta$ (poise) pada suhu $55^{\circ} \mathrm{C}$ dengan berbagai waktu curing

Tabel 2. Nilai $\mathrm{n}$ dan $\mathrm{K}$ yang diperoleh dari persamaan Power Law pada lima variasi suhu yang berbeda

\begin{tabular}{ccccccc}
\hline $\begin{array}{c}\text { Suhu } \\
\left({ }^{\circ} \mathrm{C}\right)\end{array}$ & & \multicolumn{5}{c}{ Waktu curing (menit) } \\
\cline { 3 - 7 } 40 & $\mathrm{n}$ & 0,4854 & 0,4596 & 0,3754 & 0,3372 & 0,1535 \\
& $\mathrm{~K}$ & 2,1787 & 2,1989 & 2,2441 & 2,2587 & 2,2877 \\
& $\mathrm{R}^{2}$ & 0,9930 & 0,9764 & 0,9825 & 0,9863 & 0,9908 \\
& & & & & & \\
& $\mathrm{n}$ & 0,3798 & 0,3132 & 0,2191 & 0,3001 & 0,2339 \\
45 & $\mathrm{~K}$ & 2,1686 & 2,1983 & 2,2409 & 2,2434 & 2,2679 \\
& $\mathrm{R}^{2}$ & 0,9761 & 0,9791 & 0,9776 & 0,9751 & 0,9821 \\
& & & & & & \\
& $\mathrm{n}$ & 0,2918 & 0,3269 & 0,2904 & 0,3343 & 0,5128 \\
50 & $\mathrm{~K}$ & 2,1456 & 2,1917 & 2,2119 & 2,2379 & 2,2571 \\
& $\mathrm{R}^{2}$ & 0,9678 & 0,9902 & 0,9646 & 0,9860 & 0,9757 \\
& & & & & & \\
& $\mathrm{n}$ & 0,4427 & 0,4045 & 0,2509 & 0,3013 & 0,2607 \\
55 & $\mathrm{~K}$ & 2,1202 & 2,1626 & 2,2122 & 2,2185 & 2,2239 \\
& $\mathrm{R}^{2}$ & 0,9945 & 0,9777 & 0,9906 & 0,9747 & 0,9878 \\
& & & & & & \\
& $\mathrm{n}$ & 0,3741 & 0,3633 & 0,2631 & 0,2731 & 0,2016 \\
60 & $\mathrm{~K}$ & 2,1148 & 2,1509 & 2,1639 & 2,2054 & 2,2077 \\
& $\mathrm{R}^{2}$ & 0,9952 & 0,9952 & 0,9769 & 0,9880 & 0,9772 \\
\hline
\end{tabular}

Linieritas yang baik pada Gambar 4 menunjukkan bahwa model power law cocok digunakan untuk data viskositas. Dari pemodelan laju geser power law ditampilkan bahwa koefisien determinasi $\left(\mathrm{R}^{2}\right)$ yang menggambarkan perilaku rheologi dari slurry propelan di LAPAN memiliki range dari 0,9646 hingga 0,9952 di keseluruhan suhu dan waktu curing yang diteliti. Koefisien konsistensi (K) berkisar antara 2,1148 hingga 2,2877 yang nilainya meningkat seiring dengan turunnnya temperatur. Koefisien konsistensi (K) dan indeks sifat alir (n), keduanya merupakan parameter rheologi yang menunjukkan kondisi viskositas/kekentalan suatu bahan. Hubungan antara indeks sifat alir dan koefisien konsistensi terkait erat dengan total kerja pada sistem. 


\section{TEKNIK, 40 (3), 2019, 159}

Jika kedua nilai dari parameter rheologi ini semakin meningkat maka total kerja pada sistim juga meningkat. Dengan demikian bertambahnya nilai koefisen konsistensi dari slurry propelan maka energi yang dibutuhkan oleh unit operasi (vacuum casting) untuk mencetak propelan ke dalam tabung cetakan juga semakin meningkat (Ratna, Darwin \& Mechram, , 2013).

Sedangkan nilai indeks sifat alir (n) yang bervariasi antara 0,1535 sampai dengan 0,5128 menunjukkan bahwa slurry propelan merupakan fluida Non Newtonian dengan perilaku shear-thinning (pseudoplastik) karena nilainya lebih kecil dari satu $(\mathrm{n}<1)$. Tingkat pseudoplastisitas dapat diukur dengan indeks perilaku aliran yang merupakan ukuran deviasi dari perilaku Newton. Ketika $\mathrm{n}$ meningkat, pseudoplastisitas menurun (Abhay $d k k ., 2010$ ).

\section{Kesimpulan}

Hasil pengolahan data viskositas yang ditampilkan melalui garis regresi linier pada grafik ln $\eta$ vs waktu curing, menunjukkan bahwa laju kenaikan viskositas saat penambahan waktu curing merupakan proses orde 1. Bertambahnya suhu mengakibatkan karakteristik slurry menjadi lebih encer. Sebaliknya, viskositas akan meningkat seiring bertambahnya waktu curing. Koefisien konsistensi (K) berkisar antara 2,1148 - 2,2877 yang nilainya meningkat seiring dengan turunnya temperatur. Bertambahnya nilai koefisen konsistensi mengartikan bahwa kebutuhan energi unit operasi (vacuum casting) untuk mencetak slurry propelan ke dalam tabung cetakan juga semakin meningkat. Indeks sifat alir (n) slurry bernilai antara 0,1535 - 0,5128. Dengan analisis viskositas tersebut dapat disimpulkan bahwa bahwa karakteristik rheologi slurry propelan merupakan fluida Non Newtonian dengan perilaku shear-thinning (pseudoplastik) karena angka lebih kecil dari satu $(\mathrm{n}<1)$.

\section{Ucapan Terima Kasih}

Penulis mengucapkan terima kasih kepada LAPAN yang telah memberikan dana beasiswa dan menyediakan fasilitas untuk kegiatan penelitian ini. Ucapan terima kasih juga disampaikan kepada Prof. Dr. Heri Budi Wibowo, Dr. Kendra Hartaya, M.Si dan Rika Suwana Budi, S.Si, M.Sc yang telah membantu ide, saran dan memotivasi penulis dalam penulisan makalah ini. Serta kepada rekan-rekan lab. Komposisi Dasar serta pihak-pihak terkait yang turut dalam terlaksananya kegiatan penelitian ini.

\section{Daftar Pustaka}

Abdillah, L.H., Ardianingsih, R. (2014). Equipment Process Feasibility of Propellant K-round Based on Stability Test of Propellants Properties Measuring Instruments. Proceedings ISAST II Dec 2014.
Abdulagatov, I.M., Azizova, L.A.A. (2019). Viscosity of Rocket Propellant (RP-1) at High Temperatures and High Pressures. Fuel, 235, 703-714.

Abhay, M.K., Monika, Goyal., Devendra. D, Pathak. (2010). Empirical Modelling of Chemoviscosity of Hidroxy Terminated Polybutadiene Based Solid Composite Propellant Slurry. Malaysian Polymer Journal, 5(1), 1-16.

Björn, A, De La Monja, P. S., Karlsson, A., Ejlertsson, J., Svensson, B.H., (2012) Rheological Characterization. Biogas. Rijeka: InTech.

Brookfield (2014) More Solutions to Sticky Problems, A Guide to Getting More From Your Brookfield Viscometer. Brookfield Engineering Labs, Inc.

Dak, M., Verma, R.C., Jaaffrey, S.N.A. (2008) Rheological Properties of Tomato Concentrate. International Journal of Food Engineering, 4(7).

Dombe, G., Jain, M., Singh, P.P., Radhakrishnan, K.K.., Bhattacharya, B. (2008) Pressure Casting of Composite Propellant. Indian Journal of Chemical Technology, 15, 420-423.

Marothiya, G., Chaitanya, V., Ishitha, K., Ramakrishna, P.A. (2017). An Effective Method to Embed Catalyst on AP and Its Effect on The Burn Rates of Aluminized Composite Solid Propellants. Combustion and Flame, 182, 114-121.

Hagen, T.H. (2014) Energetic Binders for Solid Rocket Propellant. Master Thesis, University of Life Sciences, Norwegia, 18-20.

Hartaya, K., Abdillah, L.H., Ardianingsih, R. (2014) Penentuan Kandungan Oksidator Berdasar Reaksi Stoikiometri Dan Struktur Kristal Dalam Rangka Adopsi Formulasi Propelan HLP. Jurnal Teknologi Dirgantara, 12(2), 102115.

Jawalkar, S.N., Mehilal, Kurva, R., Singh P.P., Bhattacharya, B., (2007) Influence of Bicurative on Processibility of Composite Propellant. Defence Science Journal, 57(5), 669-675.

Ke, Zhou., Zhongqi, He., Shupan, Yin., Wanghua, Chen (2014) Numerical Simulation For Exploring The Effect of Viscosity on Singlescrew Extrusion Process of Propellant. Procedia Engineering, 84, 933-939.

Kit, Boris., Evered, Douglas, S. (1960) Rocket Propellant Handbook. New York: The Mac Millan Company.

Muthiah, R.M., Khrisnamurthy, V.N., Gupta, B.R., (1992) Effect of Temperature on the Rheological Behaviour of HTPB Propellant Slurry. Polymer Engineering and Science, 31, 61-66.

Ratna, Darwin, Mechram, S., (2013). Simulasi Penentuan Kebutuhan Daya Pompa Pada 


\section{TEKNIK, 40 (3), 2019, 160}

Sistem Transpor Bahan Pangan Cair Dengan Menggunakan Parameter Reologi Susu Kental Manis. Rona Teknik Pertanian, 6(1), 421-425.

Restasari, A., Budi, R.S., Hartaya, K. (2018) Pseudoplasticity of Propellant Slurry with Varied Aluminium Content for Castability Development. Journal of Physics, Conf. Series 1005012034.

Setyaningsih, D. (2010) Propelan Padat Komposit. Berita Dirgantara, 8(4).
Sutton, G. P, Biblarz, O. (2001) Rocket Propulsion Elements. California: John Willey \& Sons.

Thiyyarkandy, Bejoy., Jain, Mukesh., Dombe, Ganesh. S., Mehilal, Singh, Praveen. P., Bhattacharya, B. (2012) Numerical Studies on Flow Behavior of Composite Propellant Slurry During Vacuum Casting. J. Aerosp. Technol. Manag., São José dos Campos, 4(2), 197-203. 